\title{
Dialogue
}

Women of the New Millennium: Tongan Women Determine Their Development Direction

CLARE BLEAKLEY

Making History, Becoming History: Reflections on Fijian Coups and Constitutions

BRIJ V LAL

From the Sideline: An Interview with Brij V Lal, Historian and Constitutional Commissioner

VILSONI HERENIKO

The Contemporary Pacific, Volume 14, Number 1, Spring 2002, 133-184

(C) 2002 by University of Hawai 'i Press 


\section{Women of the New Millennium: \\ Tongan Women Determine Their \\ Development Direction}

\section{Clare Bleakley}

EDITOR's NOTE: This paper is being published posthumously. The editorial board feels it is fitting testimony to the work of Clare Bleakley, whose life was cut short in a plane crash in Fiji in July 1999. A shorter version of this paper was presented at the Tongan History Association Conference, I July 1999, in Nuku'alofa. The paper was later submitted to the journal by Kerry James, who also took responsibility for overseeing a process of updating and editing that included substantial contributions from Heather Young Leslie, a reviewer for the journal who generously completed the revisions and added information on a women's land rights petition brought to the parliament by Kalisi Taumoefolau and others in I930. Young Leslie was well placed to act as a "silent coauthor" on this piece, having discussed a potential collaboration on this very subject with Clare Bleakley shortly before her death. In addition, Caroline Tupoulahi Fusimalohi, Deputy Director of the Central Planning Department in Tonga, provided further details regarding gender guidelines for government planning.

$\mathrm{I}_{\mathrm{n}}$

n the late I980s and early I990s, when gender arose as an issue in the context of development in Tonga, it tended to be dismissed in the belief that it "misconstrued Tongan culture," or that it was only, "a projection of western feminists." The high traditional and ceremonial status of women served to obscure gender as a key issue. The assumption was that the privileged status of sisters in Tongan family structures would ensure overall gender equality when combined with equal pay for equal work. However, this assumption overlooked basic imbalances in the division of labor and the distribution of authority and failed to recognize a series of relevant issues that ranged from domestic violence to the disproportionate representation of males in the civil service, politics, and senior executive positions in the private and public sectors. It also neglected the fact of women's lack of access to land rights, which Tongan women share with

The Contemporary Pacific, Volume I4, Number I, Spring 2002, I34-I47

(C) 2002 by University of Hawai'i Press 
many other Pacific Island women (Moengangongo 1986). More recent moves by some women toward gender empowerment attempt to meet these practical and strategic development needs. This paper provides a description of the activities of two local women's nongovernment organizations, the Women-in-Law Association (wILA) and 'Aloua Ma'a Tonga, which show the increasing awareness of gender as a critical component of social interaction and power relations in Tonga. They also indicate the effect that women's initiatives are having on women and on the nation as a whole as Tonga enters the new millennium.

The fact of "femaleness" alone cannot predict Tongan women's focus or their ability to contribute to the development process. As Alloo and Harcourt have pointed out, there is no necessary commonality among women's voices, nor do women always form a homogenous group or have a "feminine focus" simply because they are women of the one nationality $(1997,9)$. Instead, their skills, interests, goals and priorities, modes of operating and thinking, ways of strategizing, and global outlooks may well differ. This is as true of Tongan women as women elsewhere. Indeed, the differences provided by rank, kinship relationships, social status, level of education, access to resources, and the nature of their life experiences suggest that they will have a wide diversity of responses to development opportunities. For example, the idea that women experience universal subordination regardless of class differentials has been widely disseminated in feminist and development literature. However, rank and kinship relations in Tonga advantage sets of women differently, in ways that have implications both for development policy and its implementation.

Tongan society is strongly rank-conscious. Within the social hierarchy, no two members of a käinga (extended family) share the same rank (Kaeppler I97I; Bott 198I). Descent through a sister or through a brother of a sibling pair, for example, is particularly important in determining social rank and interpersonal behavior within the extended family. Thus, issues of women's equity and development in Tonga must be situated in socially and culturally gendered particulars if only because people are situated in kinship relations that connote different kinds of attitudes and behavior, such as command and respect, avoidance, deference, and obedience. Specific kinship duties and roles have implications for the efficacy of women's voices within family structures. In addition, family loyalty is generally likely to be stronger than a sense of shared female solidarity.

In some ways, the status of Tongan women over the past century and a half might have diminished due to church and government agendas. Com- 
bined, these have had the effect of undermining the practice of fabu: the customary claims a woman and her children have to the goods and services of her brother and his children (Gailey I996, I7I). In the modern context, the institution of fabu benefits some women and families but has become increasingly onerous to others. Today, women are disadvantaged further by ideologies, reinforced by the church and notions of tradition, that rank a wife as inferior to her husband (Kaeppler I97I; Gailey 1996). In many cases, the traditions, or angafakatonga (the Tongan way), that confine women to subordinate positions are portrayed as key, almost sacred, factors integral to Tongan identity and, therefore, nonnegotiable. These factors serve to foster the dependence of wives on their husbands and can be exploited by those who seek to maintain the status quo. However, a number of Tongan women are now challenging agendas that they have had little part in determining. Some activists have the elevated status and authority ascribed only by genealogical rank, while others have acquired a prominent social profile and prestige through education and socially approved actions. They all support the right of less privileged women to secure an equitable social position. They act for national progress or, perhaps influenced by overseas liberal arts education, out of a sense of social justice. The degree to which the members of social elites act on their ideals varies because individuals are subject to various pressures. For example, women of high rank can exercise wide social influence, but, equally, may be pressured by the members of their extended families to act solely in their interests. Nevertheless, overall in the two organizations, women activists are trying to achieve greater social equity both for themselves and for the women whom they identify as relatively disadvantaged.

The Tongan women I spoke with frequently drew a distinction between women's traditional and ceremonial status and the everyday reality of their situation. "The real power is still with the men. The privileged position of women is real, but only on special occasions when men allow women's voices to be heard," one interviewee told me ( 1996 personal communication, Nuku'alofa). The brother-sister relationship continues to show vigor in unlikely settings, for example as the template for moral behavior in legal discourse (Philips 1992, I994). Overall, however, the fahu system probably is being practiced on a diminishing scale (James I998, 39-40). As a result, as economic circumstances become straitened, women have little choice but to seek avenues other than their natal families and their brothers through which to exert influence. Education, employment, and the accumulation of assets are frequently cited as the surest paths to 
enhancing a woman's position. Increasingly, economic power, not respect, is the primary goal. For example, most women believed that earning an income advantaged them in their marital and domestic negotiations. Some insisted that it was only by contributing financially to the household that they had any significant voice in its direction. In support of this contention, young women spoke of conflicts early in their marriages when husbands expected them to conform to the traditional expectations of wifely behavior and fatongia (familial duty). The demands of the extended family on the limited finances of a young couple to support weddings, funerals, education, church conferences, and church donations, such as the misinale (annual fund-raiser), were frequently cited as major tensions that drove women to assert their independence and resist or modify these demands.

It appears that some women are becoming increasingly confident of their right and ability to negotiate what amounts to a significant change in cultural practice. It is also significant that this latitude exists precisely because there is scope within the cultural mores for people, including women, to make their own paths and, provided they have the skill, fa'iteliha (to please themselves). Much of the commentary was positive and optimistic. Tongan women I met were proud of the achievements of women in their communities. They pointed to women who worked in the higher levels of government, were involved in private enterprise or prominent in churches, had earned high academic qualifications, or had taken up leadership roles in the community as established role models. That the number of notable women was small was not seen to be the issue. The women I spoke with were proud of their collective achievements. They acknowledged that progress is slow but were encouraged by the progress they had made. The women who had successfully raised families and pursued careers were especially admired. In this regard, women pointed to the benefits of having an extended family network, within which childcare responsibilities can be shared, but they also noted ruefully that, even so, the work is still done by women.

The issue most frequently brought up as seriously discriminatory is the matter of land rights. The provisions of the 1875 Tongan constitution made all adult men eligible to claim parcels of garden land and a house site, which, once registered with the government, could then be inherited in the male line through the principle of primogeniture. Widows hold land only in trust for their eldest son, as long as they neither remarry nor fornicate. Daughters do not formally inherit land. Widows spoke to me of their vul- 
nerability and the hardship they have experienced when forced off the land by their deceased husband's family. Mothers decried the fact that their daughters would have to depend on husbands for land, and that their own family land would be passed on to their brothers and brothers' sons. Some young women said angrily that to deny women inheritance to land is unconstitutional, which it is not, and, with rather more accuracy, that it puts them at an economic disadvantage. A national priority on education has encouraged both the internal and overseas migration of large numbers of people. Formerly, women could rely for subsistence on the support of brothers and their children (the fabu system already alluded to), but this support has been weakened by the migration of extended family members in search of work, or because entire families have relocated to communities in which they have no access to land. These developments have made it more difficult for people to sustain extended family relationships, and render less readily available the benefits ideally assured to women under the fabu system. By failing to acknowledge the vulnerability of widows and single supporting mothers, the current system places them at the mercy of the kinship system as a social "safety net," but in places this is beginning to wear thin (James I997). The changes that have occurred in families, in village communities, and in urban centers such as the capital, Nuku'alofa, have come about largely as the result of fairly rapid social and economic development and have had a profound impact on women's traditional status, roles, responsibilities, and relationships. Women now argue that, since the traditional Tongan family is in the process of being redefined, they need access to land to a greater extent than they once might have done. ${ }^{1}$

"Empowerment," a current focus in development agenda, recognizes that "development" should be participatory rather than imposed. It implies the redistribution of power. Here, it is important to distinguish between power, the capacity to force compliance, and authority, which has its roots in consensus, notwithstanding the fact that consensus can be engineered through cultural expectations and constraints (Gailey I996, I77). In Tonga, authority is linked significantly to traditional practice: for example, in the case where privileged male titled chiefs lead because people agree to follow them and to give them respect and tribute. Where authority is grounded in mutual understandings, power is linked to control and, therefore, frequently experienced as male domination. Empowering women thus requires a redefinition of men's power as it is currently exercised in social interaction and relationships, and can be seen by supporters of the patriarchal status quo as a move to diminish men's power and their control of 
resources. However, the empowerment of women is not dependent on the disempowerment of men. Nor does it involve only the integration of women into existing structures, because this suggests sets of inflexible preexisting structures in which women merely have to fit. Rather, the ideal is a more equitable process of inclusion and consultation, decision-making, and agenda-setting responsibilities.

The degree to which this idea is taken seriously in Tonga will be tested by the cabinet's response to the forthcoming Gender and Development Policy-the degree to which it is incorporated into the government's Strategic Development Plan Seven, and the degree to which its genderbased initiatives become implemented. The policy will include gender relations in official national discourse by considering them in the context of the impact that current social and economic transformations are having on Tongan culture and identity. The cabinet directive for the gender policy was issued in the period covered by Development Plan Six. It has not yet been formally presented for ratification by the cabinet but is currently under consultation by various stakeholders, including women's nongovernment organizations, and government departments, committees, and ministries. One of the effects of the policy will be to bring Tongan government policy more in line with overseas aid donors' objectives. For example, education aid is well established in Tonga. The availability of donorfunded overseas scholarships has enabled a large number of students to acquire a range of postgraduate qualifications from institutions in the Pacific region or further afield. Nowadays, however, most donor governments insist on gender equity in the distribution of these scholarships. In I999, for example, the New Zealand government rejected the list of scholarship holders submitted by the Tonga Scholarship Committee, in part because the gender balance of the list was heavily skewed. Agreements for the year 2000 included provision for equal numbers of female and male scholarship holders for Australian awards, and a consistent and incremental increase in gender equity in nominations of scholarship awardees for New Zealand awards. The same criteria are to be applied to in-country training programs. Thus, the Government of Tonga's most recent gender focus is consonant with principles of gender parity. As a result, an increasing number of females are acquiring professional qualifications, vocational skills training, job placement opportunities, and a wide variety of work experience.

Despite delay in the ratification of the Gender and Development Policy, the introduction of gender as a category for consideration is an achievement in itself and acknowledges the significant role of women in 
public and private sectors in theoverall transformation process. If accepted, the proposed policy will provide an inclusive framework in which to explore and challenge current structures and procedures. Given the existing tendency of mainstream efforts to effectively submerge women's agendas in their overall focus, the new policy will enable assessment of the degree to which the inclusion of women's needs and interests in development policy and practice has been effectively carried out. It will provide an opportunity to introduce policies that address the gender imbalance in key decision-making positions, particularly in the civil service. It will also allow women to identify and mobilize around other strategic areas, such as the sharing of domestic responsibilities, equitable property rights, the provision of family and community support services, and the distribution of social, economic, and political resources. If fully supported and implemented, the policy should bring about a more even spread of power and resources. The groundwork for this kind of formal empowerment is already being prepared through several grassroots initiatives, including those of the 'Aloua Ma'a Tonga and the Women-in-Law Association.

\section{Two Women's Organizations}

The Women-in-Law Association and 'Aloua Ma'a Tonga illustrate how local women are determining their own development directions through a process of consultation with women in the wider community and by clever use of their own skills and resources. Both of these autonomous nongovernment organizations arose in the mid-I990s as a response to the perceived needs of local women. Women's nongovernment organizations are not new to Tonga. In addition, there is a well-established umbrella organization provided by the government's Women in Development Centre, which has a long history of mustering overseas financial, ideological, and organizational support for local women's development groups. The two recently formed nongovernment organizations, however, approach the goal of the empowerment of women from a different perspective and draw on different kinds of expertise. It has been established elsewhere that women's organizations are not always gender-sensitive and that not all women are always consciously aware of their own subordination or, alternatively, how they impose their will on others, especially other women (Murthy 1998, 206). Interestingly, within both 'Aloua and Women in Law, natural leaders have emerged but, in both cases, members agree that a consultative process, rather than a hierarchical or top-down command approach, is the more effective way to support the women with and for 
whom they work. This consultative approach has been an enriching and informative one for the members themselves, a number of whom remarked that, prior to their involvement, they were not aware of the real predicament of women in Tonga or the degree of marginalization, poverty, and ignorance of citizenship rights they suffered.

\section{'Aloua Ma'a Tonga}

In I995, a small number of women formed 'Aloua Ma'a Tonga as the local affiliation of an international organization, the Associated Country Women of the World. Its membership grew rapidly and by mid-I999 numbered approximately eight hundred women, many of whom had been active previously in community development and, so, quickly attracted new members. The word 'Aloua means two people paddling together in, say, a canoe. 'Aloua Ma'a Tonga thus refers to people who travel together for the benefit of themselves and their communities, and indicates that the direction of development will be successful only if it is on a single route as part of a shared vision. The membership of 'Aloua represents the broad spectrum of the community, but its focus is on the most marginalized and least materially resourced villages. On Tongatapu, these include the localities known as Popua, Patangata, Hala'ovave, and Sopu. Technically separate as villages within the Greater Nuku'alofa area, these impoverished areas contain large numbers of migrants from the outer islands who have come to the capital in search of better education and paid employment opportunities. Such areas tend to lack the cohesive kinship relations that give other communities the means for cooperative action. Also, the migrants frequently lack legal access to agricultural or residential land, and as a result are heavily dependent on the local landholders for their survival and well-being. Many migrants remain unemployed because they have few of the skills needed to compete for the relatively few opportunities for paid employment available in the increasingly densely populated capital.

'Aloua Ma'a Tonga aims to raise the profile and consciousness of rural women and urban fringe-dwellers by enhancing their skills as food producers, business entrepreneurs, and resource managers. 'Aloua is directed by the needs of the people it serves and acknowledges that women have the capacity to define their lives, even if the circumstances are not of their own choosing (Marchand and Parpart I995). In many cases, the residents of the poorer settlements have not been educated beyond basic secondary schooling, and many of them have not completed primary education. This 
fact is not always emphasized in discussions of Tongan women's traditionally elevated social status and all the implied benefits of sister respect. Women's status as sisters may be high in abstract schemes, but women in poor communities, separated from the extended family relationships that might cushion their poverty, are not regarded particularly highly and can rarely claim many significant privileges. 'Aloua members noted changes to the traditional way of life in Tonga that they believe have led to the increase in teenage pregnancies, the incidence of domestic abuse and community violence, and the deterioration of public conduct. They see a growing disparity between the circumstances of the people most able to gain access to the benefits of development and the people whose daily existence continues to be a struggle and a challenge.

Since its inception, the 'Aloua group has addressed practical needs such as water supply, landfill in swampy areas, the care and containment of domestic pigs, and home and garden fencing. The members also disseminated information about traditional medicine, healthcare, home gardening, and environmental protection. Their training of women in the skilled production of traditional handicrafts and contemporary crafts has led to the establishment of a retail outlet at the local marketplace. The success of a handmade paper venture over the past two years has led members to seek out other small enterprises that would allow them to meet regional market demands, including ones generated by the expanding tourism industry.

The 'Aloua group has trained women on Tongatapu and in the main outer island centers of Ha'apai and Vava' $\mathrm{u}$ in the construction and use of items such as smokeless stoves and drum ovens, designed to reduce both the time women spend in cooking and the amount of firewood required for cooking. More particularly, the introduction and use of the technology addresses an urgent health issue because both women and men suffer as a direct result of smoke inhalation associated with traditional open-fire cooking methods. Messages about environmental protection also are directed to women who traditionally use the local environment for their daily food, fuel, materials for manufacture, and medicine, and increasingly have to exploit diminishing resources in order to provide for their families. In cooperation with the Ministry of Education and as a contribution to community education about waste disposal, a video has been produced which illustrates the significant environmental damage being done by disposable diapers. Other activities, such as the collection of aluminum cans, point up the distressingly visible results of the increase in imported goods. 
In addition, members of 'Aloua will assist with the current implementation and monitoring of a large environment project intended to restore Tongatapu's lagoons and mangrove areas.

'Aloua was formed largely because of the recognition on the part of some women that rank and social position heavily influence women's capacity to speak and act in the broader community. The result is that non-elite and non-educated women's voices are not often heard, and both their contribution and their needs can easily be overlooked. For cultural reasons, many women, who are overly conscious of their relatively low social status, hesitate to approach women of higher rank who are well placed to assist them, despite the formal avenues open to them. However, such avenues can be costly, because traditionally the eliciting of favors requires the presentation of lavish gifts. At this level in the community, therefore, women have little real decision-making power, a situation that might now be changing, but the process is slow. 'Aloua's mandate, expressed in 1999 by one of its members, is that, "You look deep down to see who is the most needy, the women at the other end of the scale." Another member said, "You go into a community, sit down with the women and talk, and you experience their needs" (interviews in Nuku'alofa, March I999). The nongovernment organization's leaders acknowledge that their most challenging task is to motivate marginalized women to act for themselves. 'Aloua thus seeks its members' empowerment, knowing that ultimately it has to come from them, by inviting the least well-off to participate in community education and training. As a consequence 'Aloua members require a high degree of personal resourcefulness, enterprise, and energy in order to employ their particularly creative approach to appropriate development.

\section{WOMEN-IN-LAw Association}

In 1996, thirteen local legal practitioners formed the Women-in-Law Association (WILA). Currently, its members are employed by the Crown Law Department, the Ministry of Justice, the Ministry of Police, the Bank of Tonga, and private law firms. Their shared legal experience prompted them to identify areas of urgent need, such as domestic violence and child support, and their sense of responsibility motivated them to form an association through which they could act most effectively. The association's objective is to raise local women's consciousness about their legal rights. In 1998 , it launched its first major project, which focused on criminal law, 
land law, and marriage law as it affects women. Workshops have been held in all village communities on Tongatapu, and there are plans to continue this training in the main outer island centers. The response to the project has been extremely encouraging so far. It has had good levels of local participation, media coverage, an enthusiastic endorsement by the government's Women in Development Centre, and personal support from the patron, HRH Princess Nanasipau' $u$, the wife of the current prime minister.

The need to educate women about their legal rights arose from what association members perceived to be women's sense of powerlessness, in part born of their ignorance of the law. There is a need to establish rights of equality in relationships through which many women in Tonga suffer. Some problems also recognized by Women in Law, such as migrant communities that have little access to land, have been discussed already. Further, they point out that women's ignorance of custody and maintenance rights at a time when the number of divorces is increasing is likely to result in considerable financial hardship for many women because they usually carry the responsibility for childcare and support. Even more urgent is women's ignorance of their legal rights in the event of domestic abuse, which can have devastating consequences for women themselves and for their children. In Tonga it is exacerbated by the high level of shame that surrounds public knowledge of such incidents.

Some WILA members are conservative in their approach. Their preferred strategy is compromise and nonconfrontation. They believe that the information provided to women about their legal rights will pass to men and thus modify their behavior where necessary. Other members are more vocal and forthright. They regard women's ignorance of their rights as a basic denial of their access to justice. They point to what they see as a contradiction in Tongan culture that publicly elevates the status of women while privately rendering them vulnerable to male domination and, on occasion, abuse. Many feel they have a duty to represent women in legal matters in the best way possible to provide, as one member said, "a voice to the hitherto voiceless." wiLA members argue that educated women are better able to make informed choices, and they have decided to use their legal qualifications and experience to benefit less advantaged women. The support that privileged women give other women and their children, they believe, will have a long-term impact on the whole community. The workshops and seminars they provide for village women have already had a positive effect by enabling women to anticipate domestic friction and, knowing they have the right to do so, remove themselves from the situa- 
tion and take further preventive action. A survey conducted in conjunction with the seminar program will provide statistical data on women's domestic and social situations and identify their most pressing concerns. Having to deal with so many tapu (forbidden) matters, such as incest and child and domestic abuse, can be extremely awkward for women lawyers in Tonga, but these women are strongly motivated by their sense of responsibility toward other women and the overall goals of the association.

Women in Law also seeks to influence policy and legislation. Embedded in local women's experience, their strategy affirms the multiple realities of women's lives and calls for a political practice that is humane and inclusive. Currently, there are no women representatives in the Legislative Assembly and few women in key government positions where they might exert a significant degree of influence. Thus, by attempting to raise political issues the association moves into a predominantly high-ranking male domain and, by maintaining that equity in gender relations is a prerequisite for just and equitable development, challenges the dominant concept of power.

\section{A Collective Force for Change}

Both of these organizations, the 'Aloua Ma'a Tonga and the Women-inLaw Association, work from a basis of collective strength. They understand that women's empowerment is necessarily linked to self-reliance (Emberson-Bain I994, 263-274). They call for a redistribution of power that would enable women to participate in the development of their communities and voice their opinions on a range of issues that affect their lives. Their initiatives to date exercise their power, which is based on knowledge and expertise, a capacity for leadership, management skills, and innate resourcefulness. Each displays a strong sense of ownership of both their organization's vision and the projects it gives rise to. Rather than employ an approach based on notions of western individualism, both organizations generally build their human capacities for the benefit of other women and, ultimately, the wider community.

There are risks involved. Women who seek to effect change can be seen to challenge or ignore traditional roles and expectations, and to behave in ways that are un-Tongan and unfeminine, to disregard traditional boundaries, and to overstep the parameters imposed by rank. To this degree, they risk being marginalized. Women who have a vested interest in maintaining the status quo may choose to ostracize them. They are likely also to be 
criticized by men, including their own brothers, fathers, sons, or husbands, who may fear losing their authority in the family or inheritance rights to land. In Tonga, merely to talk about highly sensitive topics, such as domestic abuse, can be considered shameful. Lawyers who work on such cases constitute a threat to people who fear exposure of their own violent behavior or neglect of families, or who may see the women's professional actions generally as a negative comment on men's ability to provide for women and other dependents. Nevertheless, the members of these organizations work strategically to give all women access to information and more equitable control over resources.Ultimately, these women leaders seek to transform the power nexus in Tonga.

Some claim that there is emerging in Tonga an alternative, transformational approach to development that is grounded in the indigenous knowledge and experience of local women and men, and which acknowledges multiple social realities and cultural specificities. This is more than a claim to regain a place perceived to have been lost in the historical transitions of the last century and a half. Who, then, is the Tongan woman of the new millennium? She is a juggler of multiple roles and responsibilities, and a renegotiator of traditional family, workplace, and community relations. She identifies her own development priorities in the quest for a genderconscious social transformation. She brings energy to what she understands will be a necessarily slow and frequently testing process; she is determined, and she will be heard.

The ongoing support and cooperation of members of both 'Aloua Ma'a Tonga and the Women-in-Law Association have made this research possible. I remain indebted to them for the generosity with which they offered their time, guidance, and knowledge. A number of other women in the Tongan community have also provided considerable input and advice, by agreeing to be interviewed and in the course of our daily exchanges. I also wish to acknowledge and thank those who commented on this paper.

\section{Note}

I Tongan women's complaints about land are not new. In July 1930, Kalisi Taumoefolau, Fetu'utaki Oneone, and twenty-five others petitioned parliament for the right of women to succeed to land when no other lawful heir existed. Their petition was rejected (Tonga Gazette, I930, no I7). 


\section{References}

Alloo, Fatma, and Wendy Harcourt

I997 From the South to the North: Evolving Perspectives on Gender and Poverty. Gender and Development 5 (3): 9-I7.

Bott, Elizabeth

I98I Power and Rank in the Kingdom of Tonga. Journal of the Polynesian Society 90:7-8I.

Emberson-Bain, 'Atu, editor

I993 Sustainable Development or Malignant Growth? Suva: Marama Publications.

Gailey, Christine Ward

I996 Women and the Democratization Movement in Tonga: Nation versus State, Authority versus Power. Women's Studies International Forum I9 (I-2): I69-I78.

James, Kerry

I997 Reading the Leaves: The Role of Tongan Women's Traditional Wealth and Other "Contraflows" in the Process of Modern Migration and Remittances. Pacific Studies 20 (I): I-27.

I998 Pacific Islands Stakeholder Participation in Development: Tonga. Pacific Islands Discussion Paper Series 4. Sydney: Aus AID/World Bank Pacific Facility.

Kaeppler, Adrienne

I982 Rank in Tonga. Ethnology Io: 174-193.

Marchand, Marianne, and Jane Parpart, editors

1995 Feminism, Postmodernism, Development. London: Routledge.

Moengangongo, Mosikaka

I986 Tonga: Legal Constraint and Social Potentials. Land Rights for Pacific

Women. Suva: University of the South Pacific.

Murthy, Ranjani K

I998 Power, Institutions and Gender Relations: Can Gender Training Alter the Equations? Development in Practice 8:203-2I I.

Philips, Susan U

1992 Dominant and Subordinate Gender Ideologies in Tongan Courtroom Discourse. In Cultural Performances: Proceedings of the Third Berkeley Women and Language Conference, April 8, 9, and I0, I994, edited by Mary Bucholts and others. Berkeley: University of California Press.

1994 Local Legal Hegemony in the Tongan Magistrate's Court: How Sisters Fare Better than Wives. In Contested States, edited by M Lazarus-Black and S Hirsch, 59-88. New York: Routledge. 